\title{
The Effectiveness Of Mr Dhanis's Video On Instagram Toward Students' Vocabulary Mastery
}

\author{
Evafaliyanti ${ }^{1}$, Usmawita ${ }^{2}$ \\ Muhammadiyah University of Metro \\ Evafaliyanti1980@gmail.com
}

\begin{abstract}
Vocabulary is the central of the language and critical important that must be mastered by the students. However, most of the students just know the common vocabulary that they usually used. The use of Mr. Dhanis's video on Instagram is believed to be able to increase the student's vocabulary mastery. The aim of this research is to find out the effectiveness of Mr. Dhanis's video on Instagram toward students' vocabulary mastery. This research uses quantitave research and experiment method. The population of the research consist of 142 students at the eleventh grade students in SMA N 01 Metro. The researcher takes 62 students as the sample, then divided the students into two group, 31 students as the experiment class and 31 students as the control class. The researcher uses cluster random technique and uses t-test formula. The instruments of this research are pre-test and post-test. The result of the first hypothesis indicated that the value of $t$ obtained (13.590) was higher than that of t table (2.042) at the significance level 0.05 and the significance (0.000) was lower than 0.05 . Because of this the hypothesis is accepted. Then, the second hypothesis indicated that the value of t obtained (12.242) was higher than $t$ table (2.042). That is why, the second alternative hypothesis $\left(\mathrm{H}_{\mathrm{a}}\right)$ is accepted. It means that teaching vocabulary using Mr. Dhanis's video on Instagram at the eleventh grade students of SMA Negeri 1 Metro is effective to increase vocabulary mastery and to give a significant difference on English vocabulary mastery.
\end{abstract}

Key Words: Vocabulary Mastery, Video, Instagram.

\section{INTRODUCTION}

Vocabulary is one of the components in English that has an important role in understanding when someone is communicating each other. According to Neuman \& Dwyer (2009, p.385) vocabulary can be defined as the words must be known to communicate effectively; words in speaking (expressive vocabulary) and words in listening (receptive 
vocabulary). In English learning, vocabulary is a part that must be mastered by students, besides the fourth skills namely reading, speaking, listening and writing. It means that when the students master vocabulary, it will make the students easier to learn English. According to the competency standards of the Ministry of National Education (Depdiknas, 2013), one of the goals of English language learning in Senior High School is to develop the ability to communicate in English in oral and written forms. This communication ability includes listening, speaking reading and writing. To be able to master skills English is the absolute thing that must be owned is mastery against of vocabulary.

\section{METHODOLOGY}

The research design of this research is experimental research. Sugiyono (2016, p: 72)

states that Experimental research is a research method used to find the effect of certain treatments on others in controlled conditions. It means that this research method requires two variables to compare things to be influenced. Variables are everything that forms what is determined by the researcher to learn and to obtain information about it, and then draw the conclusions. There are two kinds of variables in common. Those are independent and dependent variable. While, Mr. Dhanis's video) as independent variable, and vocabulary mastery as dependent variables. The population of this research is the students' of the eleventh grade in SMA N 1 Metro that consist of 260 students. Then the researcher use random sampling technique to take the sample, XI IPA 3 class as experimental group there are 31 students as and XI IPS 2 there are 31 students as control class. The instrument used in this research is using test form. The tests are pre-test and post-test. Pre-test aim to measure students' abilities before learning and testing process to find a level of validity and reliability of the instrument. While the post-test aims to measure students' learning outcomes after the learning process. The collecting data of this research were taken from pre-test, treatment and post-test. In pre-test and post-test, the students were asked to do the 112 questions of vocabulary in multiple choice form of the vocabulary. Then, in treatment state the students were given the media of Mr. Dhanis's video on Instagram. 
The Effectiveness Of Mr Dhanis's Video On Instagram Toward Students' Vocabulary Mastery Evafaliyanti ${ }^{1} \&$ Usmawita $^{2}$

\section{FINDINGS}

The result of pre-test and post-test between experimental group and control group. The researcher conducted the research on April until May 2019. SMA N 1 Metro gave English schedule twice a week to the researcher, so there were two meeting in a week both of experimental and control group. In each meeting the researcher give three video about vocabulary mastery. Thus, the total of video used are twelve videos from Mr. Dhanis's video on Instagram. The chart following is the data to comparing for experimental group and control group.

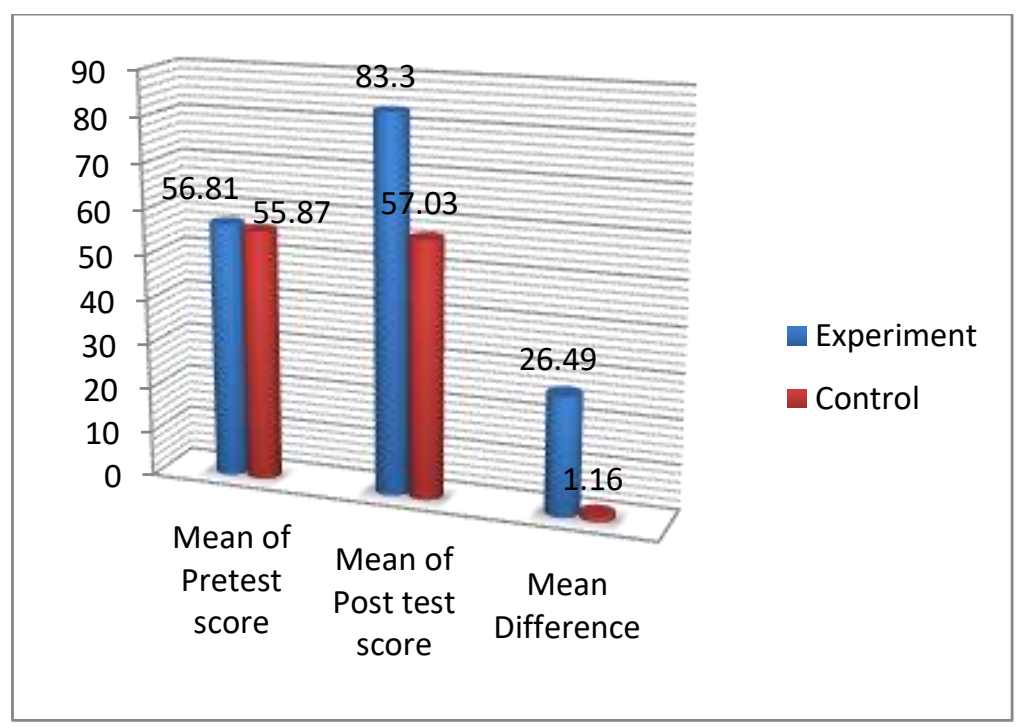

The interpretation of the data description on the table 4.10 as interpreted in chart 1 was that the mean between the experimental group and control group was different. The mean difference of the experimental group is higher than that of control group (26.49>1.16). It means that the use of Mr. Dhanis's Video on Instagram media in teaching speaking gives good result than that of without Mr. Dhanis's Video on Instagram media.

Then, to prove the hypothesis the researcher used t-test formula. The criteria for testing the hypothesis are explained as follows: if the value of t obtained is higher than that of $t$-table at the significant level of 0.05 , the hypothesis is accepted. In contrast, if the value of t obtained is lower than that of t-table at the significant level of 0.05 , the hypothesis is rejected.

From the result of pre-test and post-test in experimental group and control group, it can be concluded that there are the significances. It is caused because the experiment group get the treatment by using Mr. Dhanis video on Instagram in teaching and learning process. While, the control group did not get the treatment by using Mr. Dhanis video on Instagram, this class only gave the conventional media in teaching and learning process.

On the basis of research findings, the researcher can draw a conclusion that the implementation of Mr. Dhanis's Video on Instagram media is effective to help students in 
improving the student's vocabulary mastery. Vocabulary is very important for second language learners; only with sufficient vocabulary learners can effectively express their ideas both in oral and written form. Thus they should have a good idea of how to expand their vocabulary so that they can improve their interest in learning the language.

\section{CONCLUSION}

The use of Mr. Dhanis's Video on Instagram in teaching vocabulary for the eleventh grade students of SMA Negeri 1 Metro is effective to increase vocabulary mastery. The t-test measurement obtained is (13.590) which is higher than that of t table (2.042) at $\alpha: 5 \%$ and the probability is 0.00 . The t-test table is 2.042 out of degree of freedom (df) 30. There is a significant difference of students' vocabulary mastery before and after being taught by using Mr. Dhanis's Video on Instagram. It is proved by the t-test measurement obtained is (12.242) which is higher than that of table (2.073) at $\alpha$ : $5 \%$ and the probability is 0.00 . The t-test table is 2.042 out of degree of freedom (df) 30 .

\section{REFERENCES}

Arikunto, S. (2014). Prosedur Penelitian, Suatu Pendekatan Praktik. Jakarta. PT Rineka Cipta. Arsyad, A. (2008). Media Pembelajaran, Jakarta : PT. Rajagrafindo Persada.

Brown, H.D. (2007. Principles of Language Learning and Teaching. New Jersey: PrenticeHall.

Cameron, L. (2001). Teaching Language to Young Learners. Cambridge: Cambridge University Press.

Depdiknas. (2013). Implementasi Kurikulum 2013. Jakarta.

Hanson, and Padua. (2011). Teaching Vocabulary Explicitly. Pacific Resources for Education and Learning. London: Oxford University.

Harmer. J. (2004). How to Teach English. London: Longman

Henry and Pongrantz. (2006). Some Effects of the Nature and Frequency of Vocabulary Instruction on the Knowledge and Use of Words. Reading Research Quarterly, 20, 522-535.

Neuman, S. B., and Dwyer, J. (2009). Missing in Action: Vocabulary Instruction in Pre-K. The reading Teacher, vol.62 (5).

Read. J (2002). Assessing Vocabulary. Cambridge. Cambridge University Press.

Richards, J.C and Renandya W.A. (2002). Methodology in Language. New York: Cambridge University Press. 
The Effectiveness Of Mr Dhanis's Video On Instagram Toward Students' Vocabulary Mastery Evafaliyanti ${ }^{1} \&$ Usmawita $^{2}$

Schaefer, P. (2002). The practice: Vocabulary Development. The Education Alliance at Brown University.

Search CIO. BlogSpot. Posted by Margaret Rouse, May (2017). TechTarget.downloaded at 21.36 on Friday, April 2019.

Sudjana, N. (2005). Penelitian Hasil Proses Belajar Mengajar. Bandung: PT. Ramaja Rosdakarya

Sugiyono. (2013). Metode Penelitian Pendidikan Pendekatan Kualitatif, Kualitatif, dan R\&D. Bandung: Alfabeta.

Thornbury, S. (2002). How to Teach Vocabulary. Harlow, Essex: Pearson Education Limited. University Press. 